\title{
HEALTHCOPTER UNTUK PENGIRIMAN KEBUTUHAN MEDIS DI DAERAH SULIT TEMPUH
}

\author{
${ }^{1}$ Muhammad Khadafi Al-Af Ghani, ${ }^{2}$ Herika Hayurani, ${ }^{3}$ Mubarik Ahmad \\ ${ }^{123}$ Teknik Informatika, Fakultas Teknologi Informasi, Universitas YARSI, Jakarta
}

Email: 1daffyghani@gmail.com, ${ }^{2}$ herika.hayurani@yarsi.ac.id, ${ }^{3}$ mubarik.ahmad@yarsi.ac.id

\begin{abstract}
Indonesia is a vast country consisting of 34 provinces and 17,504 islands. Each region has a diverse geographic background. In addition, the uneven development of infrastructure which causes the transport logistics to face various challenges and problems. In the health sector, time is an important factor in the provision of emergency health needs. Therefore, the distribution of health needs such as medicines, blood and medical devices should be a major concern in improving the quality of health services. In the face of the current distribution of various problems, such as congestion, infrastructure, natural disasters, and the travel time, we propose an alternative solution in solving this problem. The solution is a drone that can perform unhindered distribution of health needs based on location coordinates of the given location. These drones in the call healthcopter are expected to improve the quality of health services in Indonesia. Healthcopter can be accessed via mobile device applications that can receive requests from various places. This research has produced Healthcopter consisting of drones and application delivery medical needs. The Healthcopter has been tested the travel time and speed based on the distance and weight of the load that can be transported by the drone. The heavier the drone load, the longer the travel time and the lower the speed. Similarly to distance, the greater the drone mileage, the longer the travel time and the lower the speed.
\end{abstract}

Keywords: Drone, distribution, health

\begin{abstract}
Abstrak
Indonesia merupakan negara luas yang terdiri dari 34 provinsi dan 17.504 pulau. Setiap daerah memiliki latar belakang geografis yang beragam. Selain itu, pembangunan infrastruktur yang tidak merata menyebabkan transportasi logistik menghadapi berbagai tantangan dan permasalahan. Di sektor kesehatan, waktu menjadi faktor penting dalam penyediaan kebutuhan kesehatan yang darurat. Oleh karena itu, distribusi kebutuhan kesehatan seperti obat-obatan, darah, dan alat-alat medis sudah seharusnya menjadi perhatian utama dalam meningkatkan kualitas pelayanan kesehatan. Dalam menghadapi berbagai permasalahan distribusi saat ini, seperti kemacetan, infrastruktur, bencana alam, dan waktu tempuh, kami mengajukan suatu solusi alternatif dalam menyelesaikan masalah ini. Solusi tersebut yaitu suatu drone yang mampu melakukan distribusi kebutuhan kesehatan tanpa hambatan berdasarkan letak koordinat lokasi yang diberikan. Drone ini di namakan healthcopter yang diharapkan mampu meningkatkan kualitas pelayanan kesehatan di Indonesia. Healthcopter ini dapat diakses melalui aplikasi perangkat mobile sehingga dapat menerima permintaan dari berbagai tempat. Penelitian ini telah menghasilkan Healthcopter yang terdiri dari drone dan aplikasi pengiriman kebutuhan medis. Healthcopter ini telah diujikan waktu tempuh dan kecepatannya berdasarkan jarak dan berat beban yang dapat diangkut oleh drone. Semakin berat beban angkut drone, maka semakin lama waktu tempuhnya dan semakin rendah kecepatannya. Begipula dengan jarak, semakin besar jarak tempuh drone, maka semakin lama waktu tempuhnya dan semakin rendah kecepatannya.
\end{abstract}

Kata Kunci: Drone, Distribusi, Kesehatan 


\section{Pendahuluan}

Indonesia merupakan salah satu negara terluas di dunia yang terdiri dari 34 provinsi dan 17.504 pulau. Setiap daerah memiliki latar belakang geografis dan geologis yang beragam. Hal ini ditunjukkan dengan adanya dataran rendah, dataran tinggi, pegunungan, dan lautan yang membentang dari Sabang sampai Merauke. Keberagaman ini belum ditunjang dengan pembangunan infrastruktur yang merata. Menurut data Badan Pusat Statistik, hampir setengah (43\%) dari permukaan jalan di Indonesia bukan aspal yaitu sebesar $221.695 \mathrm{~km}$ dari $517.663 \mathrm{~km}$ (BPS, 2014). Data ini diperkuat dengan hasil survei dari World Bank yang memberikan nilai rendah yaitu 2,92 kepada Indonesia.

Di sisi lain, penyebaran penduduk di Indonesia yang tidak merata menyebabkan kepadatan penduduk yang tinggi di beberapa kota besar. Hal ini berpengaruh terhadap transportasi dan distribusi barang. Sebagai contoh, rata-rata kecepatan kendaraan bermotor di Jakarta hanya mencapai 5 km/jam (BPS, 2014). Beberapa permasalahan $\mathrm{di}$ atas menyebabkan posisi Indonesia yang masih rendah dibandingkan negara-negara lain pada Logistics Performance Index pada tahun 2014 (The World Bank, 2014). Hal ini berdampak pada distribusi kebutuhan kesehatan seperti obat-obatan, darah, dan alat medis yang membutuhkan waktu yang cepat. Oleh karena itu, nal ini perlu diperhatikan dalam penanganan medis yang darurat dan kondisi tertentu. Pada beberapa penyakit tertentu,

penanganan medis yang lambat dapat mengakibatkan situasi yang fatal. Oleh karena itu, sudah sepatutnya aspek distribusi kebutuhan kesehatan ini menjadi perhatian khusus bagi kita dalam meningkatkan pelayanan kesehatan di Indonesia. Salah satu solusi yang diusulkan untuk mengatasi masalah distribusi kebutuhan kesehatan khususnya pada daerah sulit tempuh adalah dengan memanfaatkan perangkat drone. Beberapa contoh penerapan drone adalah pendistribusian obat pada daerah terpencil di salah satu negara bagian di

Amerika (Hackman dan Nicas, 2017), pendistribusian darah di klinik terpencil di Rwanda ( Rutkin A, 2016 ).

Dari penjelasan di atas, penulis mengajukan solusi alternatif dalam meningkatkan kualitas distribusi kebutuhan kesehatan di Indonesia. Solusi tersebut berupa Healthcopter yang terdiri dari drone dan aplikasi yang mampu melakukan distribusi kebutuhan kesehatan di daerah sulit tempuh. Drone kami pilih sebagai alat transportasi karena dapat dikendalikan jarak jauh, tanpa awak, dan meminimalisir hambatan di darat dengan terbang di udara. Healthcopter dapat menerima permintaan kebutuhan kesehatan oleh pengguna melalui aplikasi mobile. Pengguna akan mengirimkan jenis kebutuhan kesehatan dan koordinat lokasi melalui aplikasi ke healthcopter station. Healthcopter station adalah pusat kendali healthcopter yang akan mengirimkan berbagai kebutuhan kesehatan kepada pengguna.

Berdasarkan latar belakang masalah yang telah dipaparkan, maka dapat diidentifikasi masalah yang akan diselesaikan pada studi ini yaitu: bagaimana cara membangun healthcopter yaitu suatu drone yang mampu melakukan distribusi kebutuhan kesehatan di daerah sulit tempuh?, sejauh mana healthcopter dapat melakukan proses distribusi kebutuhan kesehatan di daerah sulit tempuh?

Tujuan penelitian ini adalah membangun healthcopter yaitu suatu drone yang mampu melakukan distribusi kebutuhan kesehatan di daerah sulit tempuh. Healthcopter ini dapat diakses melalui perangkat mobile dengan mengirimkan jenis permintaan dan lokasi pengguna melalui aplikasi. Adapun manfaat penelitian ini sebagai berikut: solusi alternatif dan inovatif dalam transportasi pengiriman kebutuhan kesehatan di daerah sulit tempuh, memberikan peningkatan waktu pengiriman dan akurasi dalam distribusi kebutuhan kesehatan, dan memberikan peningkatan kualitas pelayanan kesehatan dengan penanganan medis yang cepat. Batasan penelitian ini adalah: drone yang telah dibangun akan memiliki keterbatasan dalam hal jarak tempuh dan berat, daerah sulit tempuh meliputi daerah padat penduduk, daerah macet atau daerah yang tidak memiliki akses jalan, dan kebutuhan kesehatan meliputi obat-obatan, kantong darah, dan alat medis ringan.

\section{Metode Penelitian}

Berikut ini adalah penjelasan dari masingmasing tahapan pada metode penelitian ini:

\subsection{Studi Literatur}

Pada tahapan ini, penulis melakukan studi pustaka dan observasi terhadap teori, teknik, dan penelitian sebelumnya yang berkaitan dengan perancangan dan pembangunan sebuah drone. Selain itu, hal-hal yang berkaitan dengan distribusi kebutuhan kesehatan di Indonesia juga menjadi aspek yang ikut diperhatikan.

\subsection{Analisis Kebutuhan}

Tahapan ini bertujuan untuk 
mengidentifikasi kebutuhan-kebutuhan baik itu fungsional maupun non-fungsional yang menjadi elemen-elemen penting dalam perancangan Healthcopter. Penulis akan melakukan wawancara terhadap pelaku di dunia kesehatan yang berhubungan langsung terhadap distribusi kebutuhan kesehatan.

\subsection{Perancangan Healthcopter}

Tahapan ini merupakan tahapan yang paling krusial dalam penelitian. Berdasarkan hasil dari studi literatur dan analisis dari tahapan sebelumnya, penulis merancang desain healthcopter yang paling sesuai dengan tujuan. Perancangan ini mempertimbangkan berbagai aspek baik itu teknis maupun non-teknis. Hasil dari tahapan ini adalah berupa desain healthcopter.

\subsection{Perakitan Healthcopter}

Dari rancangan yang telah dihasilkan pada tahapan sebelumnya, penulis akan melakukan perakitan healthcopter. Perakitan ini akan menggunakan berbagai komponen dalam membuat drone, seperti frame, motor, GPS sensor, propeller, flight controller, kamera, baterai, remote control, dan kabel.

\subsection{Pengembangan Aplikasi}

Tahapan ini bertujuan untuk mengembangkan aplikasi yang dapat digunakan oleh pengguna untuk memanggil healthcopter. Aplikasi ini berbasis web sehingga dapat diakses oleh perangkat komputer dan mobile dengan mudah. Proses kerja aplikasi ini adalah mengirimkan jenis permintaan beserta lokasi ke healthcopter station sehingga healthcopter dapat melakukan distribusi dengan cepat dan akurat.

\subsection{Pengujian dan Simulasi}

Pada tahapan ini akan dilakukan pengujian baik dari sisi healthcopter maupun aplikasi. Pengujian ini didasarkan oleh skenario pengujian yang telah dibuat sebelumnya.

\subsubsection{Healthcopter}

Pengujian pada healthcopter ini berupa simulasi dari sisi kelayakan teknis untuk berbagai skenario. Healthcopter telah di uji pada kondisi lingkungan yang sulit tempuh dan sering macet yaitu di jalan Kartini 4, Jakarta Pusat.

\subsubsection{Aplikasi}

Pengujian ini akan berfokus terhadap fungsionalitas dari aplikasi dalam menjalankan fitur-fitur yang dimiliki. Adapun pengujian akan menggunakan metode black box testing.

\subsection{Hasil}

Tahapan ini merupakan tahapan terakhir dari penelitian. Berdasarkan tahapan-tahapan sebelumnya, penulis telah menarik kesimpulan dan dapat dijadikan dasar untuk penelitian yang akan datang.

\section{Perancangan Healthcopter}

Dalam merancang healthcopter, penulis membagi menjadi dua komponen yaitu drone dan med-box, adapun penjelasannya adalah sebagai berikut

\subsection{Drone}

Drone: Fungsi utama komponen ini sebagai alat pengantar barang yang dapat terbang melalui jalur udara dari station healthcopter yang merupakan titik awal dimana drone melakukan keberangkatan menuju lokasi yang telah ditentukan oleh pengguna. Penulis menggunakan drone DJI Phantom 4 yang sesuai dengan kebutuhan healthcopter. Drone ini dapat melakukan terbang lebih lama dari drone lainnya, selain itu drone tersebut dapat mengangkut beban kurang dari 2 kilogram, dimana drone ini dipilih oleh penulis karena sesuai dengan kebutuhan untuk pengiriman barang.

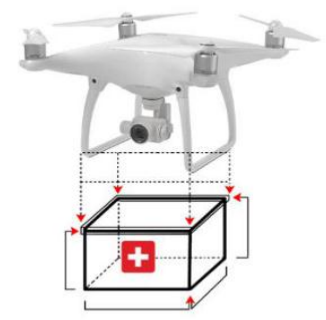

Gambar 1. Drone dan Med-Box

Adapun Drone ini terdiri dari :

\section{a. Propeller}

Propeller / Prop Adalah baling baling yang dipakai untuk memberikan daya angkat pada drone, pengendali arah, dan penyeimbang, jumlah dari propeller tersebut bervariasi, ada 
yang yang jumlahnya 2, 3, 4, 8 dan seteterusnya.

\section{b. Remote Control}

Remote control atau disebut juga $\mathrm{RC}$ yang dipakai untuk menggerakkan drone dari jarak jauh biasa di drone RC ini dipasangkan dengan device seperti smartpone, tablet, komputer yang dipakai untuk visualisasi dari drone itu sendiri dan memantau pergerakannya dari jarak jauh

\section{c. Gimbal}

Gimbal Adalah system penstabil dari kamera , juga sebagai penghubung antara drone dan camera bentuknya masing-masing berbeda tetapi memiliki kegunaan yang sama yaitu membuat stabil pengambilan foto atau video dengan menggunakan drone sehingga guncangan dari drone, dan angin tidak membuat foto mejadi goyang atau blur.

\section{d. Camera}

Camera yang dipakai untuk menampilkan image yang dipakai untuk melihat, memotret, melakukan recording video.

\section{e. Landing Skid}

Landing skid adalah kaki drone yang dipakai untuk melakukan pendaratan, bentuknya bermacam macam dan terkadang bisa digerakan naik dan turun sesuai kebutuhan.

\section{f. Shock Absorber}

Shock Absorber adalah peredam getaran yang dipakai di drone untuk membantu memberikan keseimbagan camera sehingga tetap lurus dan stabil, tidak semuanya drone memiliki ini tetapi didalam gimbal sudah ada fungsi ini.

\section{g. Rotor}

Rotor adalah dinamo penggerak dari propeller dan jumlahnya tergantung dari jenis drone itu sendiri, besaran rotornya juga tergantung dari besar kecilnya drone.

\section{h. Frame (Rangka)}

Frame merupakan tempat untuk meletakkan komponen lain dari Multicopter. Ibarat Mobil, Frame merupakan rangka dari Multicopter.

\section{i. $\quad$ Propeller (Baling Baling)}

Propeller adalah pasangan untuk motor. Untuk MultiCopter Propeller yang digunakan ada dua jenis yaitu Clock Wise (CW) / Searah jarum jam dan Counter Clock Wise (CCW) / Berlawanan Arah Jarum Jam. Ukurannya pun ada beragam biasanya dituliskan dengan format $X X Y Y$ misalnya $1045,1150,1355$, dan lain-lain, dimana nilai $X X$ menunjukkan Panjang Propeller dan nilai $Y Y$ menunjukkan Nilai Pitch dari Propeller ( dalam satuan Inch ) Memilih Propeller sendiri disesuaikan dengan Motor yang digunakan.

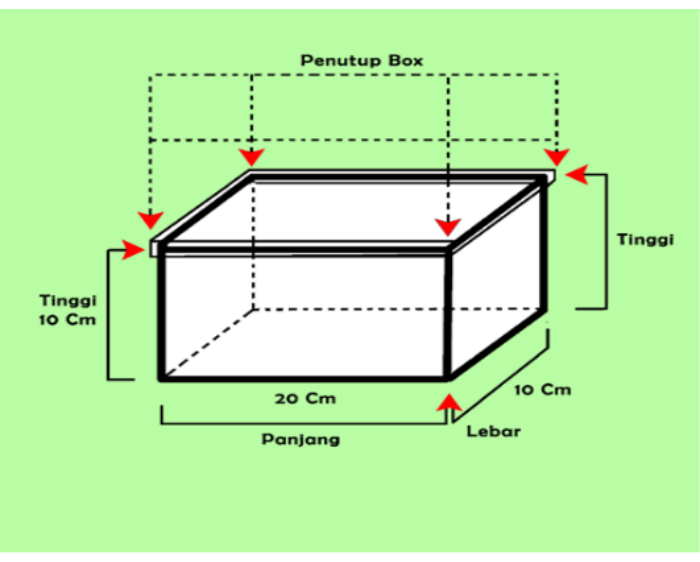

Gambar 2. Med-Box

\subsection{Perancangan Aplikasi Healthcopter}

Pada tahap ini, penulis membahas tentang perancangan Aplikasi Healthcopter. tersebut terdiri dari arsitektur, use case analysis, data flow diagram dan proses bisnis.

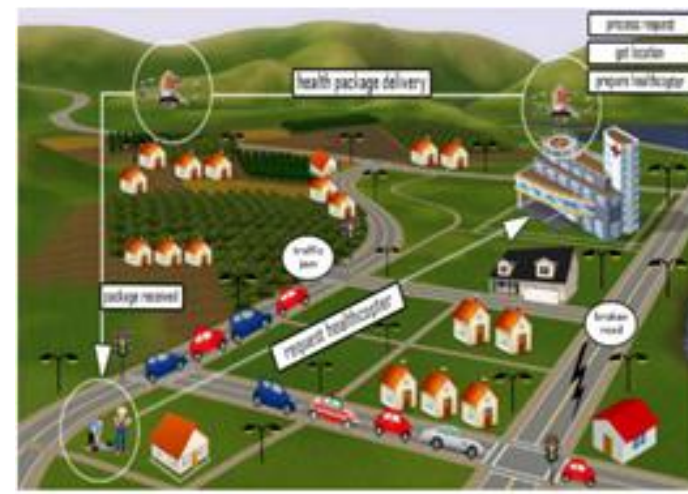

Gambar 3. Proses Aplikasi Healthcopter

User yang sedang mengalami kesulitan dan membutuhkan pertolongan medis secara cepat, user melakukan permintaan healthcopter dengan 
cara mengakses aplikasi healthcopter dan melakukan permintaan sesuai dengan kebutuhan yang dibutuhkan oleh user, kemudian admin healthcopter akan menerima sebuah permintaan dan mendapatkan lokasi dari user kemudian admin akan melihat ketersediaan yang dibutuhkan oleh user, jika permintaan yang dibutuhkan oleh user tersedia, maka admin akan mempersiapkan drone dan segera mengirimkan kebutuhan medis yang dibutuhkan terebut ke lokasi yang diberikan oleh user.

\subsubsection{Use Case}

Di dalam perancangan aplikasi ini terdapat dua buah aktor yaitu User dan Admin, User adalah Pengguna yang dapat mengakses sebuah aplikasi healthcopter, dimana pengguna dapat melakukan Register, Log in, Input Order, Lihat Order, Chatting, Live Streaming, dan Log Out. Admin adalah aktor yang mengelola dan memiliki akses penuh healthcopter. Dimana admin dapat melakukan Log in, Edit Order, Lihat Order, Hapus Order, Chatting, Live Streaming, dan Log Out.

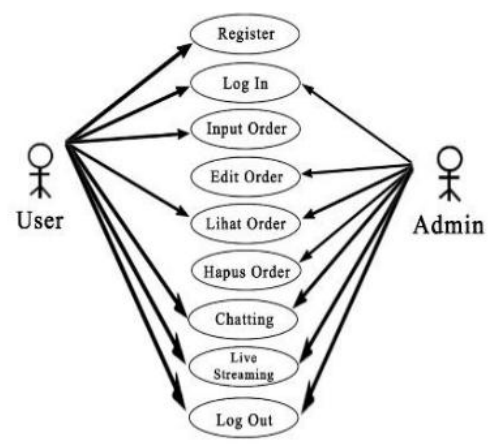

Gambar 4. Use Case Diagram

Use case pada gambar diatas dibuat untuk menjelaskan mengenai fitur atau fungsi yang dapat digunakan oleh pengguna atau aktor. Use case tersebut terdapat dua aktor dimana aktor pertama adalah admin yang mengelola aplikasi healthcopter dan aktor kedua adalah user yang dapat melakukan order kepada admin dimana data order tersebut berupa lokasi dan informasi kebutuhan medis. Tabel 1 berikut ini menjelaskan Use case Diagram
Tabel 1. Deskripsi Use Case

\begin{tabular}{|c|c|c|}
\hline Aktor & Nama Use Case & Deskripsi Use Case \\
\hline User & Register & $\begin{array}{lr}\text { Use Case ini berfungsi } \\
\text { untuk } & \text { melakukan } \\
\text { registrasi } & \end{array}$ \\
\hline User & Input Order & $\begin{array}{l}\text { Use Case ini berfungsi } \\
\text { untuk memasukan data } \\
\text { permitaan user pada } \\
\text { healthcopter }\end{array}$ \\
\hline $\begin{array}{l}\text { User dan } \\
\text { Admin }\end{array}$ & Log in & $\begin{array}{lr}\text { Use Case ini } & \text { berfungsi } \\
\text { untuk akses } & \text { masuk } \\
\text { kedalam } & \text { aplikasi } \\
\text { healthcopter } & \end{array}$ \\
\hline $\begin{array}{l}\text { User dan } \\
\text { Admin }\end{array}$ & Lihat Order & $\begin{array}{l}\text { Use Case ini berfungsi } \\
\text { untuk melihat data orderan } \\
\text { yang sudah dilakukan oleh } \\
\text { user }\end{array}$ \\
\hline $\begin{array}{l}\text { User dan } \\
\text { Admin }\end{array}$ & Chatting & $\begin{array}{l}\text { Use Case ini berfungsi } \\
\text { untuk chatting antara user } \\
\text { dan admin }\end{array}$ \\
\hline $\begin{array}{l}\text { User dan } \\
\text { Admin }\end{array}$ & Live Streaming & $\begin{array}{l}\text { Use Case ini berfungsi } \\
\text { untuk melihat video dari } \\
\text { drone yang sudah dipesan } \\
\text { langsung dari healthcopter }\end{array}$ \\
\hline $\begin{array}{l}\text { User dan } \\
\text { Admin }\end{array}$ & Log Out & $\begin{array}{l}\text { Use Case ini berfungsi } \\
\text { untuk memutuskan akses } \\
\text { pada aplikasi healthcopter }\end{array}$ \\
\hline Admin & Edit Order & $\begin{array}{l}\text { Use Case ini berfungsi } \\
\text { untuk mengubah order } \\
\text { yang telah disepakati oleh } \\
\text { user }\end{array}$ \\
\hline Admin & Hapus Order & $\begin{array}{l}\text { Use Case ini berfungsi } \\
\text { untuk menghapus order }\end{array}$ \\
\hline
\end{tabular}

\subsubsection{ERD}

ERD merupakan suatu model untuk menjelaskan hubungan antar data dalam basis data berdasarkan objek-objek dasar data yang mempunyai hubungan antar relasi. Pada aplikasi ini terdapat lima entitas diantaranya adalah Admin, Chat, User, Order User, dan Healthcopter. Adapun relasi antar entitas dapat dilihat pada Gambar 5 dibawah ini

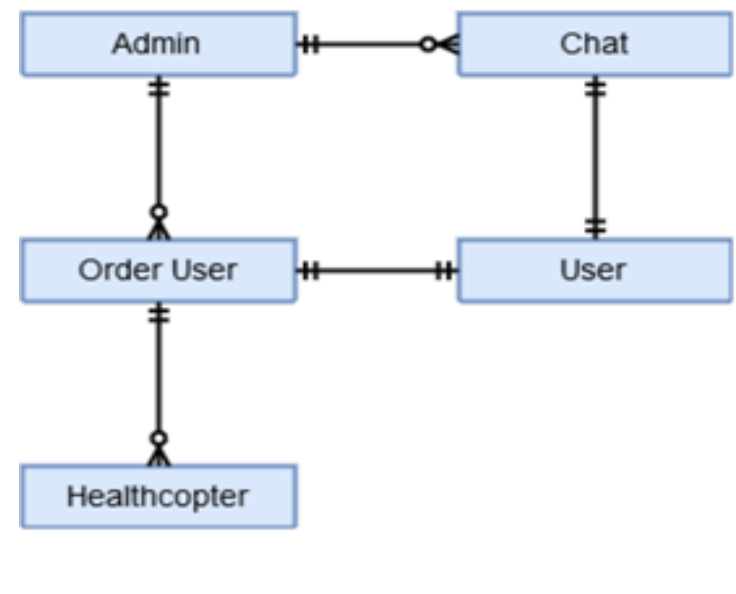

Gambar 5. ERD Healthcopter 


\subsubsection{Proses Bisnis}

Proses bisnis adalah suatu kumpulan aktivitas atau pekerjaan terstruktur yang saling terkait untuk menyelesaikan suatu masalah tertentu atau yang menghasilkan produk atau layanan (demi meraih tujuan tertentu). Dari Proses Bisnis pada Gambar 6 terlihat bahwa alur aktivitas dalam aplikasi healthcopter. Dimulai dengan user mengakses domain dari healthcopter, setelah itu user melakukan registrasi. Jika user berhasil melakukan registrasi, langkah berikutnya adalah user melakukan log in dengan memasukan username dan password pada aplikasi healthcopter. Aplikasi ini akan melakukan autentifikasi dari $\log$ in tersebut, jika valid, user dapat melakukan input order pada aplikasi healthcopter dan jika tidak valid, maka aplikasi akan menampilkan pesan tidak berhasil.

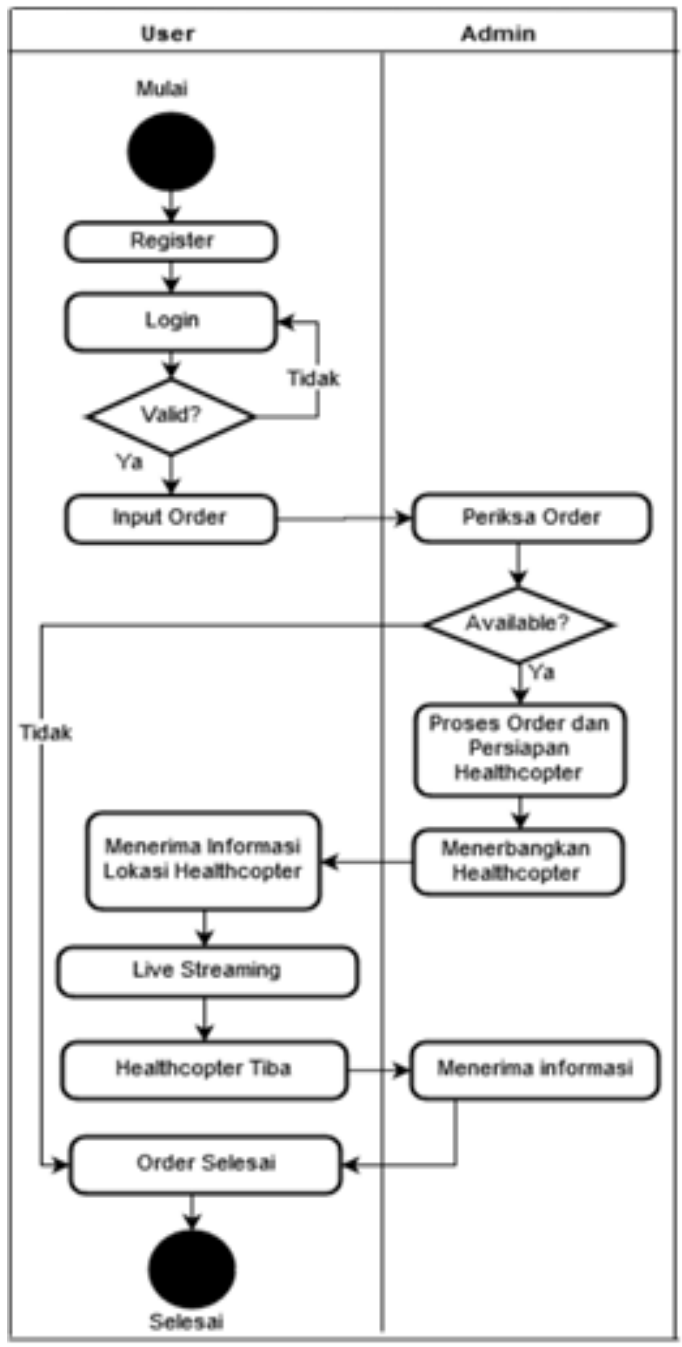

Gambar 6. Proses Bisnis
Setelah itu masuk pada halaman input order, user tersebut mengisi sesuai kebutuhan yang diinginkan. Admin akan menerima order pada aplikasi healthcopter. Selanjutnya admin akan memeriksa ketersediaan drone dan kebutuhan yang diminta oleh user, Jika drone dan kebutuhan medis tidak tersedia maka admin akan mengirimkan pesan bahwa order tidak dapat diproses. Jika drone dan kebutuhan medis tersedia maka admin akan melanjutkan proses order sampai dengan mempersiapkan healthcopter. Admin akan mempersiapkan drone dan kebutuhan medis yang diminta oleh user dan memasukan pada med-box yang sudah terpasang pada drone. Setelah itu admin akan melakukan pengambilan koordinat lokasi user dan memasukan pada drone yang sudah tersedia.

Apabila semua sudah dilakukan maka langkah selanjutnya admin akan menerbangkan healthcopter. User akan menerima informasi dan lokasi healthcopter melalui live streaming. Selain itu user akan mengetahui perkiraan waktu tiba melalui aplikasi. Jika healthcopter sampai pada lokasi, maka admin akan menerima informasi bahwasannya order sudah diterima oleh user. Kemudian drone akan kembali ke station drone dimana titik asal drone diberangkatkan.

\section{Pengujian dan Simulasi}

Pada tahap ini pengujian drone meliputi waktu tempuh dan kecepatan berdasarkan jarak dan berat beban yang dapat diangkut oleh drone. Berikut ini adalah perhitungan berat beban, waktu tempuh dan kecepatan yang dihasilkan :

Tabel 2. Jarak $0.5 \mathrm{KM}$

\begin{tabular}{lll}
\hline Berat & Waktu Tempuh & Kecepatan \\
\hline $0,5 \mathrm{Kg}$ & 1 Menit 35 Detik & $5,26 \mathrm{~m} / \mathrm{s}$ \\
$1,0 \mathrm{Kg}$ & 3 Menit 40 Detik & $2,27 \mathrm{~m} / \mathrm{s}$ \\
$1,5 \mathrm{Kg}$ & 5 Menit 23 Detik & $1,55 \mathrm{~m} / \mathrm{s}$ \\
\hline
\end{tabular}

Tabel 3. Jarak 1,0 KM

\begin{tabular}{lll}
\hline Berat & Waktu Tempuh & Kecepatan \\
\hline $0,5 \mathrm{Kg}$ & 3 Menit 56 Detik & $4,24 \mathrm{~m} / \mathrm{s}$ \\
$1,0 \mathrm{Kg}$ & 7 Menit 13 Detik & $2,31 \mathrm{~m} / \mathrm{s}$ \\
$1,5 \mathrm{Kg}$ & 12 Menit 8 Detik & $1,37 \mathrm{~m} / \mathrm{s}$ \\
\hline
\end{tabular}

Tabel 4. Jarak 1,5 KM

\begin{tabular}{lll}
\hline Berat & Waktu Tempuh & Kecepatan \\
\hline $0,5 \mathrm{Kg}$ & 6 Menit 2 Detik & $4,15 \mathrm{~m} / \mathrm{s}$ \\
$1,0 \mathrm{Kg}$ & 15 Menit 34 Detik & $1,60 \mathrm{~m} / \mathrm{s}$ \\
$1,5 \mathrm{Kg}$ & 22 Menit 30 Detik & $1,12 \mathrm{~m} / \mathrm{s}$ \\
\hline
\end{tabular}




\section{Kesimpulan}

Penelitian ini telah menghasilkan sebuah sistem berbasis web yang membantu pelayanan kesehatan dan masyarakat:

1. Sebagai solusi alternatif dan inovatif dalam transportasi pengiriman kebutuhan kesehatan didaerah sulit tempuh.

2. Peningkatan waktu pengiriman dan akurasi

dalam distribusi kebutuhan kesehatan. Peningkatan kualitas pelayanan kesehatan dengan penanganan medis yang cepat.

Pengujian drone menunjukan bahwa semakin besar beban yang dibawa oleh drone semakin lambat laju kecepatan drone tersebut.

\section{Referensi}

Apvrille, Ludovic. Roudier, Yves, and Tanzi, Tullio. 2015. Autonomous Drones for Disaster Management : Safety and Security Verifications. Proceedings of Radio Science Conference (URSI ATRASC)

Bart'ak, Roman and Vy`skovsk'y, Adam. 2015. Any Object Tracking and Following by a Flying Drone. Proceedings of Fourteenth Mexican International Conference on Artificial Intelligence.

Best Drone Info. 2016. What is Drone. Diakses pada alamat http://thedroneinfo.com/whatis-a-dronel pada tanggal 22 Mei 2016. [Online]

BPS.2014. Panjang JalanMenurut Jenis

Permukaan,1957-2014 (Km).

Diakses pada

alamat

https://www.bps.go.id/linkTableDinamis/vi ew/id/820 pada tanggal 20 Mei 2016. [Online].

Hackman, M. dan Nicas, J. (2017) Drone Delivers Medicine to Rural Virginia Clinic - WSJ, The Wall Street Journal. Tersedia di: https://www.wsj.com/articles/dronedelivers-medicine-to-rural-virginia-clinic1437155114 ( Diakses: 1 Oktober 2019).

Hyde, Dan. 2014. Everything you need to know about drones. Diakses pada alamat http:/www.telegraph.co.uk/news/uknews/def ence/11279381/Drones-UK-facts.html pada tanggal 5 Juni 2016.

Khedisfile. 2015. Sekilas mengenai apa itu drone. Diakses pada alamat http://techno.khedisfile.com/2015/07/24/se kilas-mengenai-apa-itu-drone/ pada tanggal 15 Januari 2017
Maria Rauschenberge, Manuel Pérez Cota, Jörg Thomaschewski. 2013. Efficient Measurement of the User Experience of Interactive Products. How to use the UserExperience Questionnaire (UEQ). Example: Spanish Language Version.

Robotshop. 2014. How to Make a Drone / UAV. Diakses pada alamat http://www.robotshop.com/blog/en/makeuav-lesson-1-platform-rtf-arf-kit-custom13989 pada tanggal 22 Mei 2016. [Online]

Rutkin, A. (2016) 'Blood delivered by drone', New Scientist. Reed Business Information Ltd, England, 232(3096), p. 24. doi: 10.1016/s02624079(16)31935-2

Sensefly. 2015. Should You Buy a Fixed Wing or Rotary Drone? Diakses dari alamat http://waypoint.sensefly.com/buy-fixedwing-drone-or-rotary/ pada tanggal 6 Juni 2016. [Online].

Specout. 2016. Compare Drones that Carry the Most Weight. Diakses pada alamat http://drones.specout.com/saved_search/Dr ones-that-Carry-the-Most-Weight\#guidewhat-to- look-for pada tanggal 4 Juni 2016. [Online].

Spyflight. 2016. UCAV. Diakses pada alamat http://www.spyflight.co.uk/jucas.ht pada tanggal 4 Juni 2016. [Online].

The Drone Info. 2015. What is a UCAV? It is a Unmaned Combat Aerial Vehicle. Diakses pada alamat http://thedroneinfo.com/what-is-a-ucav-itis-a-unmanned-combat-aerial-vehicle/pada tanggal 4 Juni 2016. [Online].

The World Bank. 2014. Logistics Performance Index. Diakses pada alamat http://lpi.worldbank.org/ pada tanggal 20 Mei 2016.[Online] 